\title{
8
}
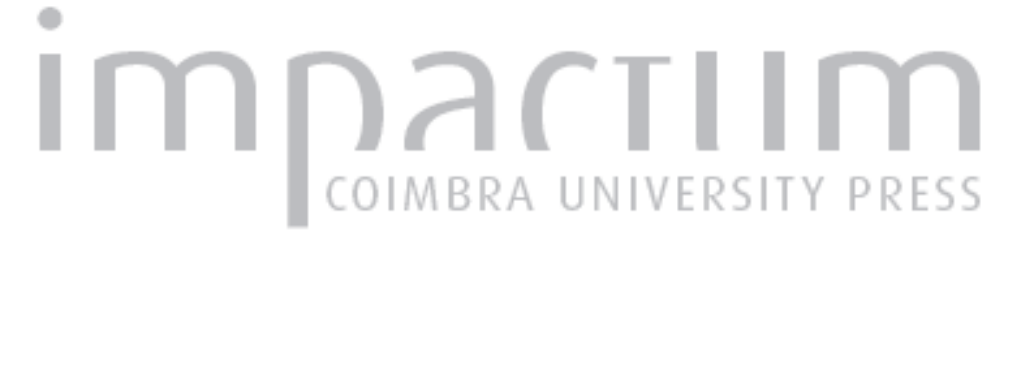

\section{Human rights against collective and organized violence: observed by Niklas Luhmann's systems theory}
Autor(es):
Dammann, Klaus Publicado por: $\begin{aligned} & \text { Faculdade de Letras da Universidade de Coimbra, Instituto de Estudos } \\ & \text { Filosóficos }\end{aligned}$

URL persistente:

URI:http://hdl.handle.net/10316.2/29467

DOI:

DOI:http://dx.doi.org/10.14195/0872-0851_41_7

\section{Accessed : $\quad$ 26-Apr-2023 13:17:41}

A navegação consulta e descarregamento dos títulos inseridos nas Bibliotecas Digitais UC Digitalis, UC Pombalina e UC Impactum, pressupõem a aceitação plena e sem reservas dos Termos e Condições de Uso destas Bibliotecas Digitais, disponíveis em https://digitalis.uc.pt/pt-pt/termos.

Conforme exposto nos referidos Termos e Condições de Uso, o descarregamento de títulos de acesso restrito requer uma licença válida de autorização devendo o utilizador aceder ao(s) documento(s) a partir de um endereço de IP da instituição detentora da supramencionada licença.

Ao utilizador é apenas permitido o descarregamento para uso pessoal, pelo que o emprego do(s) título(s) descarregado(s) para outro fim, designadamente comercial, carece de autorização do respetivo autor ou editor da obra.

Na medida em que todas as obras da UC Digitalis se encontram protegidas pelo Código do Direito de Autor e Direitos Conexos e demais legislação aplicável, toda a cópia, parcial ou total, deste documento, nos casos em que é legalmente admitida, deverá conter ou fazer-se acompanhar por este aviso. 


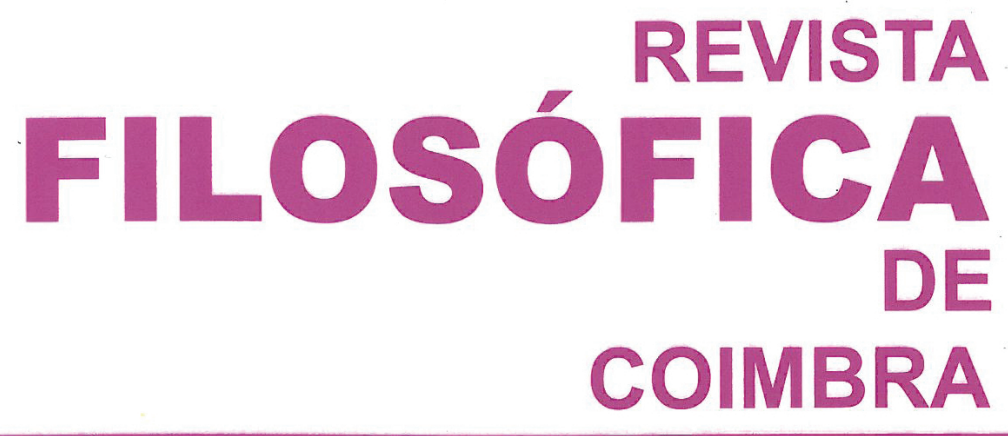

vol. 21 - número 41 - março 2012

vol. 21 - número 41 - março 2012

Fundação Eng. António de Almeida

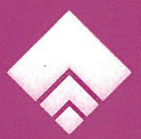




\title{
HUMAN RIGHTS AGAINST COLLECTIVE AND ORGANIZED VIOLENCE - OBSERVED BY NIKLAS LUHMANN'S SYSTEMS THEORY
}

\author{
KLAUS DAMMANN*
}

\begin{abstract}
Niklas Luhmann, from the very beginning of his theory of societal differentiation, was concerned about what today is called the human rights question. Violence is a topic maybe not less prevalent but less visible in his writings. There are three parts in this presentation:

I. A sketch of a Luhmannian theory of violence using the distinctions of

- social structure / semantics,

- action / experience ( perpetrators / victims), and

- organization / other addresses of communication ( persons, "individual/ collective")
\end{abstract}

II. Luhmanns theory of human rights

- is developed since 1965 in the framework of a theory of society: Basic rights serve (in those regions that may be named "OECD-world") to protect the basic structure of modern society : functional differentiation. Among these is the right to human dignity referring to modern society's need for individuality that is constituted by the presentation of self.

- is finished in 1995 in the framework of a theory of protest and mass media: Human rights as part of world law are work in progress distinguished from basic rights covered by national law. "Colère publique" (Durkheim) is a vehicle for producing norms, as well as for institutionalization and juridification of these norms.

Six problems have to be distinguished, starting from a theory of expectations (instead of norms):

* Professor Jubilado da Universidade de Bielefeld, Faculdade de Sociologia.

This is a slightly changed version of my presentation on 17th june 2011 in the framework of Coimbra Philosophical Lectures at the University of Coimbra. I thank Edmundo Balsemão Pires for his kind invitation. Thanks to Marc Daniel Dammann, Leeds, for trying to improve my bad English. 
- What is the content of these rights? Minimalism?

- Are there normative exspectations? In what systems? (norm production)

- Is there communicative consent assumed? And in what systems? ("institutionalization")

- Are these institutionalized norms circulating in the system of law - distinguished from the political system or from protest systems? ("juridification")

- Is this law of human rights (if there will be one) dogmatized or left to the discretion of "balancing" argumentation in courts?

- Do all persons have access to this law or does it not apply? Is it (in what systems?) switched off for certain categories of people or cases?

III. The theories supra I and II can be put together:

There are more chances for organized violence to be put on the agenda for those organizations and other systems that

- produce normative expectations on human rights

- that help to instititutionalize and

- juridify these norms.

Likewise there are more chances for violence that victimizes by ascriptive criteria to be handled like this.

This gives rise to a minimum version of human rights violations: genocidal killing, making people disappear, torture. Human dignity in a minimal version is the concept that encompasses it.

Keywords: N. Luhmann, theory of systems, violence, human rights, institutionalization of human rights, juridification of human rights.

Resumo: Desde o início da sua teoria da diferenciação social Niklas Luhmann esteve ocupado com o que hoje se chama a questão dos direitos humanos. A violência é um tema que, não menos importante, parece menos visível nos seus escritos. O ensaio seguinte tem três partes.

I. Um esboço de uma teoria luhmanniana da violência que recorre às distinções:

- estrutura social / semântica,

- acção / experiência (perpetradores / vítimas) e

- organização / outros destinatários da comunicação (pessoas, "individual / colectivo")

II. A teoria dos direitos humanos de N. Luhmann

- É desenvolvida desde 1965 no contexto da Teoria da Sociedade. Naquelas regiões que se podem chamar "mundo-OCDE" os direitos humanos servem para proteger a estrutura básica da sociedade moderna: a diferenciação funcional. Entre eles está o direito à dignidade humana que se refere à necessidade moderna de individualidade que se constitui na apresentação do Self. 
- Está concluída em 1995 no contexto de uma teoria do protesto e dos "mass-media". Os direitos humanos como parte do direito internacional mundial são "work in progress", distintos dos direitos protegidos pela lei nacional. "Colère publique" (Durkheim) é um veículo de produção de normas assim como da institucionalização e juridicialização desteas normas.

Têm de ser distinguidos seis problemas, partindo da teoria das expectativas (em vez de normas).

- Qual é o conteúdo destes direitos? Minimalismo?

- Há expectativas normativas? Em que sistemas? (produção de normas)

- Existe um consenso comunicativo assumido? Em que sistemas? ("institucionalização")

- Estas normas institucionalizadas circulam no sistema do direito - distinto do sistema político ou dos sistemas do protesto? ("juridicialização")

- A forma legal dos direitos humanos (a haver alguma) está vertida na dogmática ou é deixada à discrição do equilíbrio argumentativo nos tribunais?

- Todas as pessoas têm acesso a este direito ou não se aplica? Ele é suprimido para certas categorias de pessoas ou casos (e em que sistemas)?

III. As teorias supra em I e II podem associar-se.

Existem mais chances de a violência organizada vir a estar na agenda para aquelas organizações e outros sistemas que:

- produzem expectativas normativas sobre direitos humanos

- que ajudam a institucionalizar e

- a juridicializar estas normas

Similarmente, há mais chances para a violência que vitima segundo critérios atributivos de ser tratada assim.

Isto conduz a uma versão minimalista das violações dos direitos humanos: a morte por genocídio, o desaparecimento de pessoas, tortura. A dignidade humana numa versão minimalista acompanha-a.

Palavras-chave: Niklas Luhmann, teoria dos sistemas, violência, direitos humanos, institucionalização dos direitos do homem, juridicialização dos direitos do homem.

There are two discussions today in terms of Niklas Luhmann's systems theory which I want to put together in this paper:

Firstly there is a discussion on human rights in non-Western regions like Latin America, the Balkans, Africa and parts of Asia beginning in the 1990's and lasting until now.

Secondly there also is the question, posed since the 1990's, whether military communication distinguishes itself in modern society from other communication and forms a military system with a binary code- in war and 
in peace. This would mean that violence can be observed either as military violence or as economic, political or religious violence. For a Luhmannian discourse it is of course important that one violent act can, as communication, be included in several of these communication systems. Observing violence as a symbiotic mechanism that links power and biological systems ${ }^{1}$ does not preclude us from observing violence as communication.

Linking these two discussions the question arises, whether Luhmann's observation of the institutionalization of a human rights law is a correlate of the differentiation of military and other communication. Certain nonmilitary types of violence seem to lack the justification of military violence and, by that, they are able to attract protest and media coverage that help to institutionalize minimal human rights of the kind Luhmann describes in his observation of a world legal system.

My paper will have three parts. First I will sketch a theory of violence based on Niklas Luhmann's s theory ${ }^{2}$. In the second part I will give a short overview on Luhmann's theory of basic and human rights and descriptions connected to it $^{3}$. I will finish by linking these theories and observations, those of violence and those of human rights law. I will try to show that they are supporting themselves mutually. The theory of violence contains an empirical hypothesis of the ethics of violence.

\section{A Luhmannian theory of violence}

Niklas Luhmann often presents lists of functional spheres that may or may not be function systems in the sense of his theory constructed in the 1980s: systems closed by a binary code. Other authors propose other spheres. There are now about 30 candidates for function systems in society. About half of

${ }^{1}$ See: Niklas Luhmann Symbiotische Mechanismen (1974) in: Soziologische Aufklaerung 3. Opladen 1981: 228-244.

2 There are sketches of a Luhmannian theory of violence in two of my papers: Voelkermord und Terrorismus. Die soziale Konstruktion von Unschuld der Opfer in Semantik und Sozialstruktur, Bielefelder Arbeiten zur Verwaltungssoziologie 2003/3; Wovon reden wir, wenn wir mit Luhmann Gewalt in Lateinamerika beobachten? Bielefelder Arbeiten zur Verwaltungssoziologie 2008/1 (available from: klaus.dammann@uni-bielefeld.de).

${ }^{3}$ See Klaus Dammann, Niklas Luhmanns These zur Funktion der Grundrechte. Verfassungspatriotismus, Menschenrechtsphilosophie oder schlicht Soziologie? In: Veith Mehde/Ulrich Ramsauer/Margrit Seckelmann (Hg.): Festschrift für Hans Peter Bull zum 75.Geburtstag. Berlin 2011. For a short presentation of Luhmann's book on basic rights (1965) in a non-German language: Holmes/Larmore's translator's introduction in: Niklas Luhmann, The Differentiation of Society, New York 1982: xxii-xxvi. A newer overview in: Chris Thornhill, Niklas Luhmann and the sociology of the constitution, in: Journal of Classical Sociology 10 (2010) 315-337. 
them are well discussed by now. NL mentions the military sphere but does not propose a code that the system uses to discriminate between system and its environment ${ }^{4}$.

There has been a debate about how we can think of a military system. Is it a system separate from the political one, similar to the legal system that NL proposes in the 1970s? Or is it a subsystem of the political system ${ }^{5}$ I will not discuss this question because in my reasoning only the binary code is important.

It seems to many observers of NLs theory of society that military communication is not differentiated from politics. Until the beginning of the 1970s NL did not even write about a differentiated legal system to be distinguished from the political system. But law, as NL observes later, is not only created or used by state agencies like courts, parliaments and so on. Non - state agents can, by contract, produce law and litigate about it in private organizations. Law is communication that refers to the binary code of legal/illegal. ${ }^{6}$ No-state semantic is included in this code - as it is in the case of political communication. The political system is indeed constituted by the code: to have state power/ not to have it.

So why not conceive of military communication as a sphere that is independent from the state and is constituted by a code that encompasses all kind of destructive organizational communication, even from those organizations that describe themselves as doing religion or business, as for example Djihad or drug dealing? Different codes have been proposed for observing this kind of military communication not confined to traditional interstate wars or traditional political guerilla warfare. I suggest a code hypothesis that can be used to distinguish military communication from other systems, in peace as well as in wartime.

This code, empirically observed is: "to destroy organized destroy capacity by means of organization, yes or no". Military communication always refers to this dual potential, on the one side: to wage war, to prepare a war or just to wait for war, and on the other side, in times of war: to destroy an enemy organization's visible destroy capacity now or to wait until a better opportunity arrives. Of course the military title of an organization is not important. Police or business organizations too may prepare and wage wars in this sense.

If there are no organizations on either side that observe each other's preparation or implementation of violence one will have to look at

${ }^{4}$ E.g. Niklas Luhmann, Gesellschaftliche Grundlagen der Macht : Steigerung und Verteilung (1981), in: Niklas Luhmann. Soziologische Aufklaerung 4, Opladen 1987: 123.

${ }^{5}$ See Tobias Kohl, Zum Militär der Politik, in: Soziale Systeme 15 (2009) 160-188.

${ }^{6}$ One of the first statements from 1972 and 1973/4: Niklas Luhmann, Ausdifferenzierung des Rechts, Frankfurt a.M. 1981: 78f., $267 \mathrm{ff}$. 
something different than military communication. It may be individual murder, it may be collective killing or looting called pogrom when there are no perpetrator organizations. And when violence is not directed to organizations it may be genocide or genocidal massacre. Or it may be violence under conditions, when a modern social structures full of organizations meets very different structures, as in the case of the so called colonial genocide.

This coding of military communication apart from political, economic, religious and family violence is a component of social structure. It is reflected in what NL calls the semantics included in societal descriptions. Let us have a look at these semantics?

\begin{tabular}{|l|l|l|}
\hline $\begin{array}{l}\text { Diagram: Labeling collective serial killing: leading distinctions (distinctions directrices) } \\
\text { in English, French, and German language discussion of genocide since } 1944\end{array}$ \\
\hline \multicolumn{2}{|c|}{ victims selected: } \\
attribution to \\
perpetrators:
\end{tabular}

${ }^{7}$ For an empirical study of these semantics: Klaus Dammann, Die Armenische Katastrophe-Genozid, Pogromwelle, Krieg, Bestrafung oder was sonst? Eine soziologische Untersuchung semantischer Opportunitaetsstrukturen zur Leugnung von Voelkermord, Bielefelder Arbeiten zur Verwaltungssoziologie 2001/1 (available from klaus.dammann@, uni-bielefeld.de).

${ }^{8}$ See full bibliographic in Dammann 2001 (Footnote 7 above). 
The semantics of violence uses perpetrators / victims as its leading distinction, which is a specification of NLs distinction of action and experience in communication.

In my diagram you can see the results of an empirical study on semantics that you will find in several function systems. Very special semantics of function systems like the law is excluded. It is a case study that can be replicated, a method NL uses in his numerous semantical studies since 1965. In describing the results I simplify a little. I do not use a constructivist language but use the notions of warfare, genocide and pogrom, as if this phenomena exist independently from communication. To call it bellification, genocidalization and so on, when violent communication is described by help of semantics, would be more exact.

If you ask how forms of violence are constructed by semantics you first need to demarcate your topic to avoid discussions of psychic violence or structural violence that are absent in NLs work but very common in political language. So I choose serial killing as my topic, killing that is "collective" because the perpetrator is an organization or more than one non-organizational actor. Luhmann does not use the distinction individual/ collective- unlike mainstream sociology. Population catastrophe would have done it either. You can hear of the Jewish, the Armenian, the Palestinian catastrophe in native languages: Shoa, Aghed, al-Nakba. And of course you can identify the catastrophes of the two world wars or the one of Aids in Africa or, on a smaller scale, the catastrophes in Lybia and Syria right now in the news.

The perpetrators are distinguished by attribution: Is violence attributed to organizations or to what is called "mob", "crowd", "movement" "clans" (and so on, instead of individual perpetrators)?. By using mob, crowd (and so on) collective units are constructed that have no address- unlike organizations.

Looking at the victimization process the criteria of victimization are distiguished by using ascription / action. The vast majority of at least 5,4 million Jews that were killed by German organizations from 1939 onwards were murdered because they were considered as Jews and not because they acted in some specific way, e.g. as partisans in the framework of organizations fighting one another. Soldiers, including of course partisans, are killed as infrastructure of their organization, when this organization acts in a certain way, that is when their organization (or the soldier himself at least) does not surrender.

Of course there is a semantic struggle about using the two-fold distinction of organizations / non-organizations and ascriptive / action. In what sense are civilian populations active that are bombed in the enemy's cities? And there are many supplementary distinctions used for calling 
some serial killing genocide or war, may it be a terroristic war and a war on terror. We can see this in the Armenian catastrophe. Armenophile historiography that wants the central Ottoman or Atatuerk government to be responsible is not satisfied, when other organizations are found that murdered in the years 1915 to 1922 instead of the central government. So the struggle is about this question: Was there a central decision? And can the Turkish Republic be seen as the successor of the Ottoman empire? ${ }^{9}$

This could already be a sufficient demonstration of how Luhmann's theory can be used for violence analysis. Niklas Luhmann's theory also gives us hints about the chances of how to construct a law of human rights using social structure and the semantics of collective and organized violence. I will sketch these hints after describing Luhmann's view on human rights.

\section{Luhmann's theory of basic and human rights}

It was in 1965 when Niklas Luhmann published his first book on the theory of society and suggested some spheres into which modern society was differentiated in a functional way. This book from 1965, today translated in Japanese, Italian and Spanish ${ }^{10}$, contains a simple sociological thesis which I divide into three steps:

1. The functional differentiation of society is endangered.

2. Basic rights are directed to this societal problem: they serve the function to keep the functional spheres separate. For sociology of course basic rights of course are social structures - if you can find them. Luhmann at that time called them "institutions", and these structures, but not legal texts, have to be analyzed.

3. There are no functional equivalents for basic rights as social structures: The separation between politics / administration / public and the autonomy of the central bank are only special structures and cannot fulfill the overall function.

Niklas Luhmann never repealed this statement about basic rights until his last books on the theory of society.

\footnotetext{
${ }^{9}$ See Klaus Dammann, Footnote 7 above.

${ }^{10}$ Niklas Luhmann, Grundrechte als Institution. Ein Beitrag zur politischen Soziologie, Berlin 1965, translated: Niklas Luhmann, Los derechos fundamentales como institución. Aportación a la sociología política, trad. Javier Torres Nafarrate, México, D.F.: Universidad Iberoamericana, 2010.
} 
The 1965 statement was elaborated by the example of the Constitution of the Federal Republic of Germany, founded in 1949, when Luhmann finished his law studies. It can be considered a case study like the many others Luhmann designed in the $1970 \mathrm{~s}$ and $1980 \mathrm{~s}^{11}$. The thesis is on regions where there is functional differentiation and where this differentiation is not severely modified like in what Luhmann calls "total" states (total in brackets). He mentions Nationalsocialist Germany and "developing countries". The Soviet Union and its satellites are examples for Luhmann of both variants of societal structure - total and developing. We may speak of an OECD - world which is covered by the Luhmann - thesis, Mexico and Turkey maybe excluded.

Starting 1968 Niklas Luhmann created the notion of world society. We are living in one society - Brazil, Portugal, Spain and Germany being only names for political, and legal structures but not for whole societies. Society encompasses far more than this, for example the economy, arts, sports, education and science, function systems that in no case can be restricted to regions like Portugal or even Europe, but nowadays form function systems of one society, called world society. Portugal, Germany, Europe and so on are names for segmentary systems or organizations inside these worldwide function systems. Nowadays even law and politics are to be seen as worldwide systems, but including prominent segments and organizations with national or regional names: nation "states" or the European Union.

There exists a short discussion on whether and how the Luhmann thesis on basic rights is related not only to the OECD regions but also to world society encompassing those Asian, African and Latin American regions where functional differentiation is modified or even absent what concerns law and politics. The most convincing proposition is that the functional differentiation of world society is secured by national basic rights in the OECD world. World society's functional differentiation uses these basic rights in a parasitic way. Those who participate in world commerce, foreign investment and world politics have their rights on propriety and life also safeguarded, of course. But this works through a sector-specific world law: lex mercatoria, lex internet and so on and not by universalistic rights, such as "human" rights.

${ }^{11}$ His most prominent case study is one on semantics: O amor como paixão (1982), Lissabon 1991. Luhmann's book on basic rights (see Footnote 10) consists of two semantical studies (Chapters 2 and 3) and another case study on the structure of society (the case being Germany from about 1949 onwards). 
In his last work, for example the conference he held in a national Brazilian lawyer's meeting in $1994^{12}$, Luhmann looks at human rights as "work in progress". There seems to develop a human rights law by means of what Durkheim called "colère publique". But the content of this developing law is restricted to a minimum of rights all related to human dignity. The assaults on these rights are torture, killing by ascriptive criteria, making people disappear. We see, that all these affronts are not directed against inclusion as persons, not against "personal" rights, but against "bodys and souls", excluded human beings. These rights are "human" rights in a narrow sense ${ }^{13}$.

Distancing himself from those philosophers and lawyers who try to show that there should or can be a consent on human rights, be it in a maximal, a minimal or a moderate version, Luhmann insists on a sociological analysis. His skepticism and his minimalist description of human rights derive from his sociological theory of expectations that offers many distinctions that mainstream law and ethical discussions do not have ${ }^{14}$.

Firstly, in the factual dimension of meaning, we have to describe which human rights we see in world society. Luhmann's book of 1965 is not only a sociological study but also an attempt to dogmatize the German basic rights. He described human dignity by means of the notion of self presentation, found in Erving Goffman's work. Dignity does not presuppose human essence. In his words of 1965: "The essence of essence is unknown"15. It is the individuality of persons that is constructed in the social sphere by help of a right on dignity. This is already a restricted version, a minimal version of dignity. NL knows that basic rights conflict and he advocates legal dogmatics not to give courts the unlimited possibility to decide how to solve this conflict. In a process of balancing rights the results cannot be foreseen. So legal dogmatics should construct

12 Niklas Luhmann, Ética e Procedimento nas relações internacionais, in: Anais XV. Conferência Nacional da Ordem dos Advogados do Brasil 4. - 8. Septembro de 1994, São Paulo 1995:148-156; published later in German as: Ethik in internationalen Beziehungen, Soziale Welt 50 (1999), p. 247-254.

13 See a distinction between personal/human rights that corresponds to a distinction inclusion/exclusion: Gunther Teubner, Die Anonyme Matrix: Zu Menschenrechtsverletzungen durch "private transnationale Akteure", in: Der Staat 45 (2006)175.

14 There are two analyses in law and philosophy that use Luhmann's sophisticated view: Andreas Fischer-Lescano, Globalverfassung. Die Geltungsbegründung der Menschenrechte, Frankfurt a.M. 2005, and Johannes Schwerdtfeger, Die Menschenrechte im Rahmen der Moderne und ihrer Krise, in: Hans-Richard Reuter (Hrg.), Ethik der Menschenrechte, Tübingen 1999: 11-41.

15 See: Grundrechte als Institution (footnote 10 above), pages 59, 60. 
rights in a restricted way, that means: not as values, but as potential structures fulfilling functions.

Secondly, we have to look at the temporal dimension of meaning. We have to ask: Is, what is called human rights, a set of normative or cognitve expectations? Luhmanns theory of normativity uses Johan Galtung's distinction between cognitive and normative exspectations and recognizes norms only when expectations are not abandoned after being disappointed. When, at the beginning of this century, we look at the Darfur or even now at the Lybian conflict we can doubt if rights of people are seen in a normative way by all governments or all mass media. In respecting the sovereignty of nation states many discussions look at law in a cognitive way - in terms of legal or (more directly) political risk. Do we risk something by not intervening? Other questions are only asked by some of the actors of world politics: Are there human rights that can be brought to court? Is there even a duty of humanitarian intervention, because otherwise human rights law cannot be protected? There is some attention in the discussion of a law of world society to Luhmann's observation that the institutionalization of normative expectations faces social structural obstacles that are special to world society ${ }^{16}$.

The third distinction covers the social dimension: can there be an assumed consensus observed on a minimum of human rights? As for the question of normativity in this case we also have to look at whereever consensus is assumed. Widespread consensus, that Luhmann describes, does not mean that every national political system, for example Northern Korea, or every movement, every agency and political party in Western countries shows consensus. In his early years Luhmann called the process of assuming consensus institutionalization. So for him basic rights in post - world war Germany were institutions. But soon he must have realized that this was used by his opponents to link him to the theory of institutions of, e.g. Arnold Gehlen, darling of right wing political thinking and philosophical anthropology. He abandoned the word, the term institution but not the concept of assumed consensus ${ }^{17}$. The distinction of

16 See: Marc Amstutz/Vaios Karavas, Weltrecht. Ein Derridasches Monster. In: Gralf-Peter Callies et al. ( Hrg.), Soziologische Jurisprudenz. Festschrift fuer Gunther Teubner zum 65.Geburtstag. Berlin 2009: 655f.

${ }^{17}$ Luhmann did cite Gehlen's books, but his theory never used the political implications of this conservative's concepts. And since about 1966 Luhmann did not any more need anthropology: man was since then a topic for biology. The one article in Portuguese language that contains a concept of institutionalization (Niklas Luhmann, Religião institucionalizada segundo a sociologia funcional, in: Concilium. Revista internacional de teologia, 91, 1974: 34-44) was produced at the request of an editor from the USA. The concept is 
expectations, may there be cognitive or normative ones, on the one side and assumed consensus for these expectations on the other side remains a very important part of Niklas Luhmann's sophisticated theory.

The fourth distinction refers to functional differentiation of world society. Since the 1970's Niklas Luhmann acknowledges a separate legal system of society. So even if we find norms of human dignity, and widespread consensus for them we still have to ask if these norms are political or legal ones. The symbol of legal validity must be conferred to institutionalized norms for being able to observe a law of human rights.

It is about this fourth distinction too, about the question of juridification Luhmann was talking about to Latin American lawyers. There he described public enragement, colère publique, about the violation of human dignity ${ }^{18}$. It is a long way for sociological observation from an ethics of human rights to a law of violations of human dignity. The shorter way is a theory of normativity that overlooks the possibility both of cognitive expectations and lack of assumed consensus and uses a semantics that takes the legal character of rights as given.

This already sophisticated set of distinctions recommended for human rights analysis is not even complete.

Since his 1965 book Niklas Luhmann is interested in dogmatics. A human rights law needs dogmatics to hinder the courts to balance conflicting rights in a way that cannot be foreseen. This is a fifth distinction.

And a sixth distinction is brought forward for taking account of human rights violations in Nationalsocialist Germany, during Latin America's military governments and in this world region of today. Even if there is a legal system and an institutionalized human rights law the law can be abondoned ("switched off" as Luhmann calls it) for certain categories of people, for Jews, for gypsies, for political enemies, for street children and prostitutes in the inner cities. This resembles the famous "dual state" analysis of Nationalsocialist rule by Ernst Fraenkel: This state applied its own law only for parts of the population and not for all cases ${ }^{19}$. The Luhmann distinction of inclusion/exclusion can be linked to this switching off of law: If people are excluded from legal communication they are not

not that of Gehlen, but of Talcott Parsons - not only due to the expectation of getting an North American audience.

18 See Niklas Luhmann (footnote 12 above).

${ }^{19}$ Ernst Fraenkel, The Dual State: A Contribution to the Theory of Dictatorship (1941), New York 1969. There is a good secondary analysis of Fraenkel's concept: Horst Dreier, Was ist doppelt in Ernst Fraenkels "Doppelstaat"? In: Franz-Joseph Peine/ Heinrich Amadeus Wolff (Eds.), Nachdenken ueber Eigentum. Festschrift fuer Alexander von Bruenneck zur Vollendung seines siebzigsten Lebensjahres, Baden-Baden 2011: 412-433. 
yet reduced fom persons to mere bodies. But this reduction, if it happens, comes along with exclusion from other function systems that are important for daily life.

\section{Support for the evolving human rights law}

How can theory relate Niklas Luhmann's human rights account to functional differentiation of violence communication?

Are these semantics of violence and these violent social structures of modern society linked to the beginning juridification of an institutionalized norm of human dignity?

In my diagram's four fields we can make out two fields where violence is attributed to organizations. Luhmann's sociology tells us that for attributing action all communication needs addresses. In modern society there are only two types of addresses: persons and organizations ${ }^{20}$. Only these two types of actors can be held responsible for violations of human rights constituted by law. Organizations are, unlike crowds of persons, privileged in committing large scale mass murder - that is the thesis of Zygmunt Bauman ${ }^{21}$. On the other hand organizations and people acting for organizations can be held accountable more easily - you only need a small amount of the organization's members on trial, in court, to show symbolically what is expected in a legal normative way from organizations.

But what about excluding field number two from the core of human rights violations? Warfare is attributed to organizations- in social structure as well as in semantics. Of course field two includes action labeled as war crimes. Some of it can be attributed to organizational units and not to individual people in non-organized populations of soldiers (gang raping for example). They may be included in military communication. But when it comes to sanctioning human rights violations in Luhmannian theory there is a focus not on action criteria, but on what I have called ascriptive

${ }^{20}$ In certain circumstances Luhmann acknowledges that an interaction, e.g. of a group or crowd, maybe even during a pogrom, can be addressed by adressing a leader - if such a leader evolves who is able to stop the violent communication.

${ }^{21}$ This thesis may be disputed (see my paper: Genocide and the Modernity of Organizations. Organizational Rationality - New Support for a Discredited Idea? Bielefelder Arbeiten zur Verwaltungssoziologie 2009/1, available from: klaus.dammann@uni-bielefeld. de). But if you take certain types of techology of mass extermination into account, in contrast to fire, knifes and automatic rifles that are used extensively in pogroms, organizations seem to be more able to have and use these devices. 
criteria. Function systems are indifferent to ascriptive criteria that cannot be related to their code. They need this indifference for recruiting persons at least to participate in their client roles, if not even in staff roles ${ }^{22}$. Killing people chosen by ascriptive criteria is empirically possible under conditions of functional differentiation but contrary to the normative expectations inherent in this form of differentiation. It is not without interest that until now all well known international court cases have been cases of human rights violations under conditions of regional variation of functional differentiation: German nationalsocialism, Post- Yugoslavian ethnonationalism, African tribalism, Latin American autoritarianism. When functional differentiation englobes the political and the legal system, that is: in the "OECD-world", evidence for choosing victims by ascriptive criteria and a state's action (including some non-action) lacks. For sure we see more or less violent (and more or less organized, but seldom deadly) action against illegalized immigrants - but getting into a country without permit is attributed as action. People are not seen as persecuted by selecting them through ascriptive criteria, even if visible non-western background may have selective results.

So in Luhmannian theory human rights violations in field 1 of my diagram are a very special case. These violations are easily calling for attention by public enragement. It is this type of victimization, called genocide, genocidal massacres or, in Hannah Arendts terminology, administrative mass murder, that has all chances of producing normative expectations, producing assumed consent for the norms and juridifying these institutionalized norms.

But not only what is shown in my diagram: proven killing of people by organizations, but also making disappear people and most cases of torture are covered by the process of juridification. This is explained by the mass media attention that can be mobilized for these types of human rights violations too.

Making people disappear seems to be a good indicator of victim's choice by ascriptive criteria. If the killing organization would have been able to attribute action to the victims, e.g adherence to an opposition or even terrorist movement, no need for making them disappear would have arisen. This at least is an assumtion that underlies most protests against this kind of violence.

What about torture? Torture is sometimes applied to people in the context of their actions. It is interesting that torture for saving lives is a

22 For this universalism of function systems see Luhmann, from 1965 (Footnote 10 above, 177ff.) towards the end of his publication career: Die Gesellschaft der Gesellschaft. Frankfurt a.M. 1997: 1051,1075. 
much disputed case of torture, in contrast to torturing a confession from someone. Niklas Luhmann refers to the "ticking bomb" scenario in one of his lectures but does not see how the law can treat this problem ${ }^{23}$. In contemporary German constitutional law this is discussed as human dignity being in conflict with human dignity. So the undisputed cases of torture are those in which people are not tortured as a reaction to action (including non-action defined as action). The victims of torture are labeled "innocent" as other victims that are chosen by ascriptive criteria.

What about attempts of blurring boundaries between fields one and two? Let me illustrate the problem by two examples:

1. There is a scenario that Holocaust perpetrator agents have used to justify the killing action. At least one German SS-general and the Bulgarian authoritarian prime-minister of 1943 too have asked: What is the difference between the Holocaust killing and the case of assembling Jews on a field and then killing them by bombing from above as the allied air forces did with the civilian population of cities as for example Hamburg and Dresden? In the same vein but with different intentions some liberal American social scientists are labeling the Hiroshima and Nagasaki bombing of autumn 1945 genocidal bombing. Some analysts of the distinction between war and genocide would say that the difference is in the military use of the cities of Hamburg, Dresden, Hiroshima and Nagasaki. This military use makes the civilian population killing a collateral damage of what appears in communication as an intentional warfare action. But others would even renounce of this criterion and analyse each bombing of a city in the enemy's territory as warfare because it may contribute to surrender and by this effect spare lives.

We must acknowledge that in Luhmannian theory a war waged (that is military communication in an armed conflict) is neither a legal nor a moral category. The law system has a different code than to the military system. And by this difference of codes decision programs produce the label illegal, attached to some warfare action. Warfare action may be legal or illegal. Maybe the Hiroshima bombing was observed as illegal in 1945. The legal system creates war crimes. And it creates the crime genocide. But this legal distinction is different to the distinction of genocide and warfare that occurs outside the legal system. Killing organizations (police, army, militia, guerilla and others) create this difference without consulting lawyers.

${ }^{23}$ Niklas Luhmann, Are There Still Indispensible Norms in Our Society? In: Soziale Systeme 14 (2008) 18-37. 
2. Another attempt at blurring boundaries has been started by some German historians. They analyzed the Second World War and adapted Stalin's and Hitler's terminology of annihilating the enemy. First they found a "war of annihilation" at the Eastern front since 1941. Today more and more World War II warfare has been analyzed in terms of annihilation. And for some historians even the annihilation of Central, Eastern and Southeastern European Jews form part of this "war" of annihilation.

With a little help by Luhmannian theory we can assume that military communication is not about annihilating people but about destroying the organized enemy's destroy capacity. Then we are able in times of war to distinguish between military killing on the one side and genocidal killing on the other side. Military killing stops when the enemy's organizations or parts of it, even individual fighters surrender. Indeed in World War II for many people there was not an option of surrender. More than a million captured Soviet and ten thousands Italian soldiers had already surrendered when they were deliberately killed, mostly by starvation. And the Millions of killed Jewish people, women, children, older people included, and the civilian population of sieged Leningrad were not asked to surrender but even prevented from doing so. It can be shown empirically that Nazi German communication did differentiate between military killing and non-military killing. The "war of annihilation" semantics is not supported by socialstructural communication. Annihilation, genocide can be observed, and war can be observed. This may occur in times of war and even some causality may be attributed to war: war favors genocide in it's shadow. All this does not affect the hypothesis of a functional differentiation of the military ${ }^{24}$.

My last point is: Some kind of assumed ethical consensus seems to be supported by the social-structural differentiation of military from genocidal communication. And this consensus supports differentiation.

Military communication, including organized terrorism, is privileged in ethics and morals compared to genocidal violence. If you look at the bookshelves of libraries on social philosophy (maybe in the rooms of this distinguished university) or just google "war" and "genocide", you will easily find new books and essays on the disputed question of just war and even on just terror violence as a special type of warfare. There are universalistic ethics of just war $^{25}$ and even of just terrorism, justified e.g.

24 See my paper, War of Annihilation' or 'War and annihilation in Times of War'. Researching a Distinction in Semantics and Social Structure, Bielefelder Arbeiten zur Verwaltungssoziologie 2007/1, available from: klaus.dammann@uni-bielefeld.de.

25 See for a modern version: Michael Walzer, e.g. Just and Unjust Wars. A Moral Argument with Historical Illustrations, New York $2^{\text {nd }}$ edition1992. 
for defense against war or against oppression ${ }^{26}$. But I did not succeed in finding one single example of a discussion of just genocide, genocide in the broader sense of organized serial killing of people choosen by ascriptive criteria. For very specific historical incidents of this type of killing in the modern world you find ad-hoc justifications, for example those playing with blurring distinctions. That does not preclude an argumentation of "dirty hands" 27 . But this stresses, by the label "dirty", how dubious this kind of killing is from the standpoint of general ethics: "if everybody would act in the same way.....". For the Jewish catastrophe, called Shoah or Holocaust, you do not even find ad-hoc justifications any more. Holocaust negation works by negating facts, because there is no longer a semantic way to justify. This shows empirically the unique uniqueness of the Holocaust. The core of the killing was organizational and the mass of the victimized population was chosen by ascriptive criteria. They were not partisans.

There is and was (during times of modernity) also no law of genocide that would correspond to ius ad bellum or ius in bello. I suppose that the semantics of just war, which is of older origin, did accompany the differentiation of military and genocidal violence during the 19th century as a "preadaptive advance" 28 . Nowadays it supports this very differentiation 29 .

So there is consistency between a Luhmannian theory of violence and Luhmann's view of the way a law of human rights is evolving in our world society. And besides consistency there is data that supports this view.

${ }^{26}$ See e.g.: C.A.J.Coady/ M.O'Keefe (Eds.), Terrorism and Justice: Moral Argument in a Threatened World, Carlton South, Vic. 2002.

27 See Michael Walzer (1973), Political Action: The Problem of Dirty Hands, Philosophy and Public Affairs, 2, 1973 (2): 160-180.

28 See for his notion Rudolf Stichweh, Semantik und Sozialstruktur: Zur Logik einer systemtheoretischen Unterscheidung, in: Soziale Systeme 6 (2000) $243 \mathrm{f}$.

${ }^{29}$ I do not describe the corresponding legal semantics. Paradoxically the legal and ethical privilege of military violence can contribute to disprivilege genocidal victims. After 1944 victims of warfare were legally and in public attention preferred to victims of genocidal persecution. See for a "competition of victims" e.g Jean-Michel Chaumont, La concurrence des victimes. Génocide, identité, reconnaissance, Paris 1997. 